\title{
VCO の直接位相制御による高速ビット位相同期回路
}

\author{
正 員 太矢隆士 (蝤電気工業) 非会員 吉田 聡 (沖電気工業) \\ 非会員 山岡信介 (電気工業) 非会員 松本修一 (沖電気工業) \\ 非会員 吉田良和 (神電気工業)
}

A High-Speed Bit Synchronization Circuit by the Direct Control of the Oscillation Phase of a VCO

Takashi Taya,member, Akira Yoshida,nonmember, Nobusuke Yamaoka,nonmember,

Shuichi Matsumoto,nonmember, Yoshikazu Yoshida,nonmember

(Oki Electric Industry Co., Ltd.)

\begin{abstract}
In a large scale broadband communication system, thousands of high-speed serial data interconnections are used and a bit synchronization circuit (a clock and data recovery circuit) is required in each of the receiver side interconnection circuit. In this paper, the requirements and the implementation of a bit synchronization circuit for the interconnection are considered, and one solution is proposed. In the proposed circuit, the oscillation phase of a VCO is directly controlled by the trigger signal extracted from the input data. Synchronization capturing is quick and the circuit is applicable to a burst signal. The circuit tolerates jitter and phase variation of the incoming data. The circuit requires no external components, and is suitable for an integrated circuit. The circuit has been implemented using a $0.5 \mathrm{~m}$ CMOS process and the data recovery operation from a $440 \mathrm{Mbps}$ pseudo-random pattern was confirmed. Data acquisition is accomplished within three clock periods from a $440 \mathrm{Mbps}$ burst data.
\end{abstract}

キーワード : ビット位相同期回路，電圧制御発振器(VCO), シリアル伝送，バースト信号，クロック

\section{1. まえがき}

ディジタル信号の高速シリアル伝送路の受信側に必要と なるビット位相同期回路は, 装置の高速化・大容量化を実 現するうえで重要である。通常この部分は装䈯内で最高速 のディジタル信号の 1 ビット以内の分解能を持つ処理が必 要であり，純粋なディジタル化恃困難で，アナログ回路の 忘用が勃果的と期待される。

通信装置などにおいて, ある程度以上(例えばボード間) の距灕にわたってディジタル信号を伝送するためには, 図 1(a)に示すように，データ信号と，データ信号の区切り を示すフレーム信号，そして対応するクロック信号をまと めて伝送する必要がある。

受信側装置ではこのクロック信号を用いてデータ信号お よびフレーム信号を処理する。信号速度が50Mbps 超え ると, 装置内程度の伝送距雄でもディジタル信号 1 ビット あたりの時閒に対して伝送路の遅延時間が無視できなくな る。このような場合にデータ信号, フレーム信号, クロッ ク信号を別個の線路で伝送すると受信側での到達時間に差

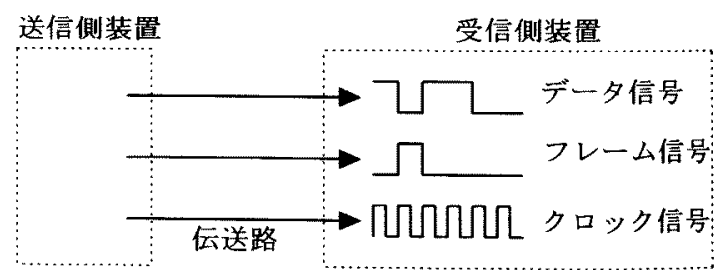

(a)

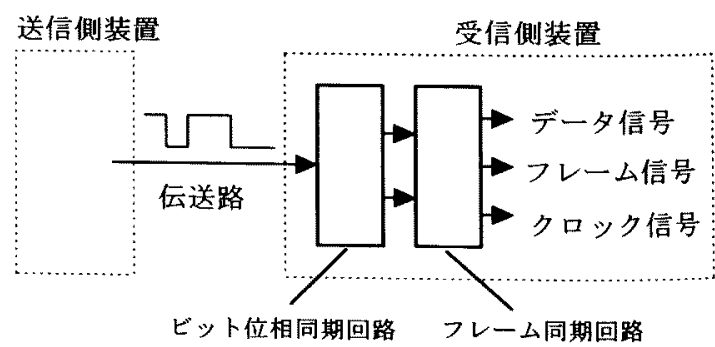

(b)

図 1 ビット位相同期回路の適用

Fig. 1. A bit synchronization circuit 
が生じ，信号の再生が困難となる。したがってこのような 場合には図 1(b)に示すようにデータ信号のみを伝送し，受 信側装置においてデータ信号, クロック信号およびフレー 么信号に対忍する情報を再生することで信号伝送が実現で きる。ビット位相同期回路はデータ信号の各ビットと，そ れを処理するクロック信号の位相同期を実現する回路であ 万。

従来この種の回路は数 $\mathrm{km}$ 以上に㧍よぶケーブル，ある いは光ファイバ伝送の受信側において，タンク回路などを 用いてクロック抽出を行うことによって実現されてきた。

近年通信装置の扱う信号速度が格段に大きくなり，装置 内に挍いても $100 \mathrm{Mbps}$ 以上の信号線が何百本も行き交う ようになってきているため, 数 $\mathbf{m}$ 程度の信号伝送において もビット位相同期回路が要求される場合が增加している(1)。 また装置内の布線本数，コネクタピン数が装置のデータ処 理能力のネックとなってきていることから，フレーム信号 線，クロック信号線を無くして信号線数を减少させるため にビット位相同期回路の適用が望まれる場合もある。この ような装置内で多用されるビット位相同期回路に求められ る条件は長距晟伝送などに用いられてきたものとは大きく 粠なる。

ここでは上記のように装置内で多用される場合における ビット位相同期回路の持つべき特性と実現方法について検 討し，集積回路化に適した回路方式を提案し，実験結果を 報告する。

\section{2. ビット位相同期回路実現上の条件}

装置内で多用されるビット位相同期回路の赛現を考える 際，考慮すべき条件を以下にまとめる。

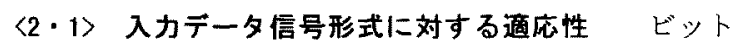
位相同期回路は入力データ信号のビット位相情報を知る必 要がある。極端な例では全ビット”0"が連続するような NRZ信号にはビット位相情報は皆無であり，入力信号はあ る頻度で変化することが必要である。言い換えると同符号 連続量には上限が必要である。ビット位相同期回路は同符 号連続の期間，位相情報を保持する必要があるため，一般 に同符号連続量が少ないほど実現は容易である。

同符号連続量に上限を設けるために，送信側装置におい て伝送路符号化が行われる。CMI 符号, nB1C 符号, ブロ ック符号 $(4 \mathrm{~B} 5 \mathrm{~B}, 8 \mathrm{~B} 10 \mathrm{~B}$ など)を用いることにより同符号連 続量の上限を確実に設けることができるが，伝送路に必要 な帯域は符号化しない場合より增大(CMI 符号で $100 \%$, 4B5B 符号で 25\%)する。一方スクランブラの適用は伝送路 に必要な帯域の増大をもたらさないが，長い同符号連続が 起こる確率がゼ口にはならない。伝送路符号は伀送路の直 流成分の抑制やフレーム信号の伝送も考虑し，さらに各種 規格で標準化されており，適用装置によって仕様として与 えられるものであるから，ビット位相同期回路はその仕様 に適合する特性を持つものを選択する必要がある。
データ信号としては常時データ信号が連続して任送され ているものと，バーストとして伝送されるものがあり，ビ ット位相同期回路に求められる特性も大きく異なる。バー スト信号を再生するためにはビット位相同期回路の位相捕 捉は急速に(例えば数ビット以内に)行われる必要がある。

〈2・2〉クロック分配経路長距離伝送の場合には, 受信したデータ信号からのクロック抽出が唯一の手段であ るが，装置内などの場合には受信側において，送信側のク ロック信号が，デ一タ信号とは別経路で得られる場合が女 る。このような場合には受信側のビット位相同期回路は別 経路から得られたクロックとデータ信号との位相差の調整 のみの機能とできるため，実現が容易となる場合がある。

〈2・3〉 入力信号の歪みおよびジッタ特性 伝送路を通 して人力されるデータ信号には振幅方向抢よび時間軸方向 の歪みが発生しており，ビット位相同期回路の動作に大き な影響を与える。一般にビット位相同期回路において信号 誤りの発生は許されないため，綮密な設計が必要である。

時間軸方向の歪みがジッタであり，ビット位相同期回路 は入力データ信号に含まれるジッタに対しても唄りなく動 作することが求められる。ジッタは入力デ一タ信号の位相 変調と考えられ, その位相変調周波数と位相変動量とで規 定できる。

データ信号からクロックを抽出するタイプのビット位相 同期回路で，その抽出クロックを後段の装置で使用する場 合には，抽出クロック中のジッタも問題となる場合がある。 受信側の装置のローカルクロックにデータを載せかえる場 合にはあまり問題とならないが，抽出クロックで後段の装 置が動作する場合にはジッ夕(入力に含まれていたジッタ が後段に伝送されるものと，ビット位相同期回路でクロッ ク抽出を行う際に生じるもの)に対して厳しい要求がなさ れるほか，伝送路が遮断した場合でも後段へのクロック供 給が必要となる等の条件がある。

〈2・4〉コスト要因 ビット位相同期回路を装置内で 多用寸るためには，そのコスト要因老考虑寸る必要がある。 条件として考えられるものを以下に示す。

(1)外付部品：コイル・キャパシタや压電素子による共振 回路が必要な回路は一般に高価で, 小型化も困難である。

(2)調整：タンク回路，VCO などの調整が必要であるよ コスト增につながる。

(3)検查容易性：一般には全ディジタルの構成が有利であ る。

(4)回路規模：ディジタル回路は一般に大規模化する。

(5)消費電力 ・電源電生

(6)回路動作速度

これらの条件をすべての場合について満足することは不 可能であり，要求仕㥞により最適な実現方法を選択するこ とが重要である。 


\section{3. ビット位相同期回路の実現方法}

従来より実現されているビット位相同期回路について述 べ，装置内で多用する用途への適応性について考察する。

〈3・1〉 タンク回路によるビット位相同期回路 入力 シリアル信号に含まれるクロックの周波数成分を LC や圧 電素子で構成された共振回路に入力することによりクロッ クを再生する。共振回路としてQ 值の高いものを用いるこ とにより入力データ信号の長い同符号連続に耐えることが 可能で, 入力データ信号のジッタや歪みにも強くできる。 さらに抽出・再生したクロックのジッタも極めて小さくで きる。しかし全集積回路化した場合と比較して極めて高価 かつ大形となり，かつ共振周波数をデー夕速度に正確に合 わせるため共振素子に対する精度要求が㛜しくなったり， 調整が必要となったりするため，装固内で多用することは

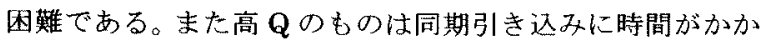
るため,バースト信号には適用できない。

〈3・2〉PLL 回路によるビット位相同期回路 PLLを 用いるビット位相同期回路は, PLLの集積回路化が容易な ことからさまざまな回路方式が提案されている。PLLのル 一プ特性を適宜設定することにより最適な特性を持つビッ 卜位相同期回路が実現できると期待される。しかし位相比 較器とループフィルタとVCOの代単純な構成では， VCO の中心周波数精度が高い場合や, 入力データ信号とし て CMI のような符号を用いた場合にのみ㬰用的であり，

一般に集積回路化を前提とするとオンチップ VCO には中 心周波数の精度が期待できないため，かなり複雑なループ 構成を用いる等の工夫が必要である(2)(3)。

〈3・3〉 ディジタル処理によるビット位相同期回路 入力データ信号より十分高速のクロックで動作するディジ タル回路を用いれば，入カデータ信号をその信号速度より 速い速度でサンプリングすることによりビット位相同期を 実現することができる。例えば入力データ信号を4倍の速 度でサンプリングし，データの変化点を検出して最適なサ ンプリング点のデータを出力とする(4)等の方法がある。主 要な機能をディジタル回路で寒現できるため, 集積回路化 に適しており，無調整で検查も容易である。一般には回路 は複雑で規模も大きいため消費電力が大きく，またジッタ や歪みの多い入力信号には対応が難しい。

高速のデータ信号の数倍以上の高速で動作するディジタ ル回路による処理は，高価で消費電力も大きくなるので, 純粋なディジタル処理によるのではなく，遅延素子や多相 クロックなどを用いて時間分解能を上げ，データ信号と同 程度以下の速度の回路で実琴することが実用的である。特 に装置内における信号伝送のように，送信側のクロック信 号がデータとは別経路で受信側に供給できる場合に有利で あり，さまざまな方法が提案されている(5)。

\section{VCO の直接位相制御によるビット位相同期回路}

以下 VCO の直接位相制御によるビット位相同期回路に ついて紹介し，既に述べた各種実現方法との比較を行う。

\section{〈4・1〉Vcoの直接位相制御によるビット位相同期}

タンク回路によるビット位相同期回路は，入力デー夕信 号によってタンク回路を励振させるものであるが，同様の 現象は入力データ信号をVCOに直接結合させることによ っても実現できる。このような事例としては図 2 に示すよ うに 1960 年代以前にマルチバイブレータ発振回路にトリ ガ信号を注入することによって分周機能を実現した例があ る(6)。

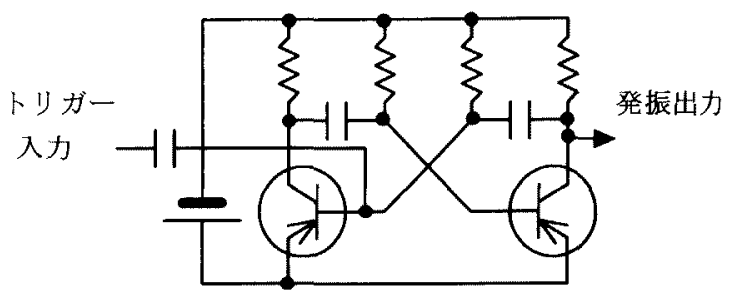

図 2 マルチバイブレータ発振回路による分周器

Fig. 2. Frequency divider using a multivibrator

図 2 の回路におおいて，トランジスタ 2 個で構成された無 安定マルチバイブレータは例えば約 $25 \mathrm{kHz}$ で自走発振す るように抵抗值およびキャパシタ值を設定し，トリガー入 力に例えば $100 \mathrm{kHz}$ の信号を入力し，キャパシタによって マルチバイブレータに瑓結合すると，発振出力にはトリカ 一入力に位相が一致した $25 \mathrm{kHz}$ の分周出力が得られる。 れはマルチバイブレータの発振位相がトリガー入力によっ て制御されることによって起こる現象である。

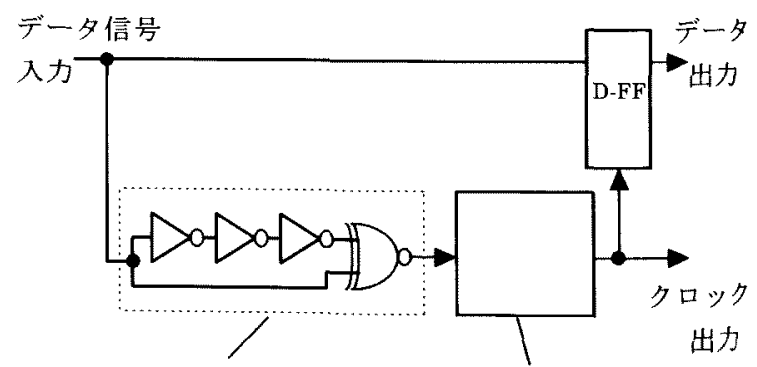

位相制御トリガパルス 直接位相制御回路付 VCO 生成回路

网3 VCO の直接位相制御によるビット位相同期回路

Fig. 3. Bit synchronization using a Direct Phase Controlled VCO 
この現象はビット位相同期回路のクロック抽出に適用す ることができる。すなわち抽出すべきクロック周波数付近 で自起する発振器の発振位相を, 入力データ信号の位相情 報を持つトリガパルスで直接制御することができればビッ 卜位相同期機能が実現できる。この現象を応用して, 図 3 のような構成でビット位相同期回路を実現できる(7)(8)。

図 4 に各部の信号波形を示す。まず入力データ信号の変 化点を検出し, VCO 一の位相制御トリガパルス齐生成する。 このトリガパルスによって VCOの発振位相は直接制御さ れ，入力データとのビット位相同期が実現する。

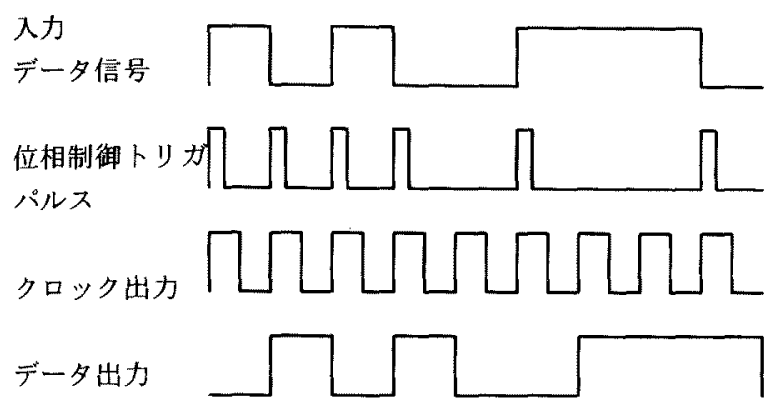

図 4 図 3 の動作波形

Fig. 4. Operating waveforms of Fig. 3

〈4・2〉VCO の直接位相制御図 3 に示す回路を実用 化するためには，集積回路化可能な VCOにおいて発振位 相を直接制御する必要がある。

エミッタ結合型マルチバイブレ一タの発振位相を，外部 からのトリガパルスで直接制御できるようにした回路を図 5 に示す(7)。

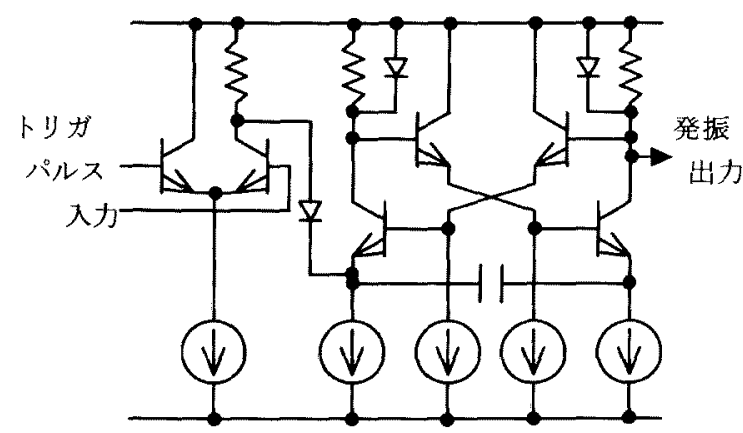

図 5 直接位相制御可能な

エミッタ結合マルチバイブレータ回路

Fig. 5. A Direct phase controlled emitter coupled multivibrator

この回路においてタイミングキャパシタの左端の電位を卜 リガパルスによって強制的に上昇させることにより発振位 相を制御することができる。すなわちタイミンダキャパシ 夕に左方向に電流が流れ，左端の電位が下降しつつある期
間にトリガパルスを印加するとマルチバイブレ一タの状態 遷移を遅らせるため発振位相を制御することができる。

さらに低電圧動作可能で，高速動作に適した発振回路を 図6に示す(9-14)。図中央の双安定マルチバイブレー夕を左 右の差動回路でトグルさせることによってSRフリップフ ロップとして動作させ，2 個のタイミングキャパシタを充 放電させてリラクセーション発振を行う。左右の差動回路 に 1 個づつのトランジスタを付加することにより，トリガ 入力による発振位相制御を実現している。

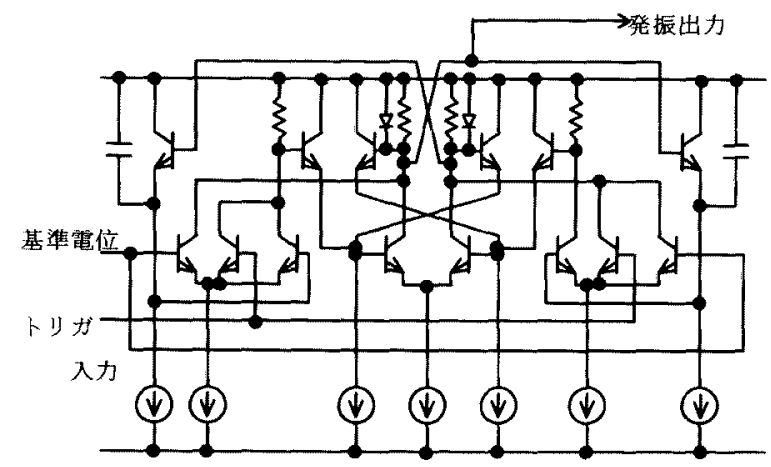

図 6 直接位相制御可能な

リラクセーション発振回路

Fig. 6. A Direct phase controlled relaxation oscillator

図7に CMOS トランジスタで構成された回路を示寸 (15)(16)。2 個のオンチップキャパシタと SR フリップフロッ ブとで構成されたシラクセーション発振回路を用い，発振 ループ内にゲートを配置して位相制御を妾現している。

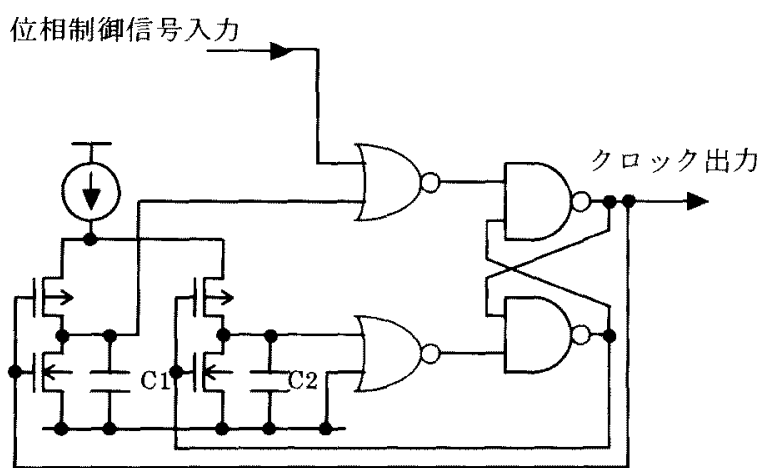

図 7 直接位相制御可能な CMOS VCO 回路

Fig. 7. Direct Phase Controlled CMOS VCO

図 7 に示卞回路の位相制御動作波形を図 8 に示す。 図 8 (a)は位相制御トリガパルスが入力されない状態で, 2 個のキャパシタ $\mathrm{C} 1$ と 2 が交互に充電され，しきい值に 達すると SR フリップフロップがトグルして自走発振を行 5 。 
図 8 (b)に示す位相関倸で位相制節トリガパルスが印加 されると,C1 が充電されて次段ゲート(NOR)のしきい值に 達する前に SR フリップフロップがトグルしてしまうため, 発振位相は進む。図 8 (c)に示寸位相関倸で位相制御トリガ パルスが印加されると，C2 が充電されて次段ゲートのし きい值に達しても SR フリップフロップがトグルすること を妨げるので発振位相は遅れる。図 8(d)に示す位相関係で 位相制御トリガパルスが印加された場合には，発振位相は 変化しない。位相制御トリガパルスのこのような作用によ り，VCOは入力データ信号に同期して発振する。

位相制御トリガパルスは入力データ信号の変化点に対応 してダート遅延を利用して生成している。発振出力のデュ 一ティー比劣化を避けるため, トリガパルス幅がクロック 周期の半分以上とならないように設計する。

\section{位相制御}

トリガパルス

C1 電位

C2 電位

発振出力

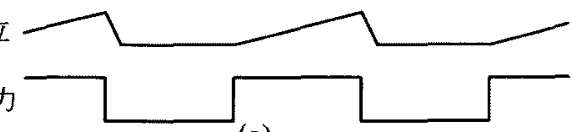

(a)

\section{位相制御}

トリガパルス

C1 電位

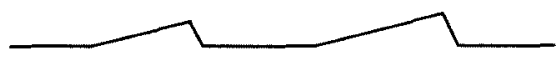

C2 電位

発振出力

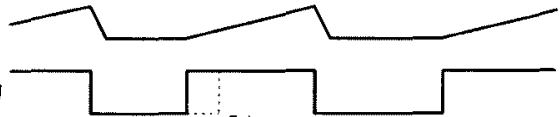

(b)

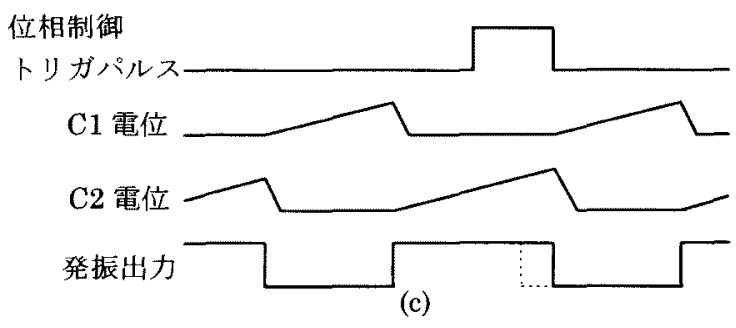

位相制御

トリガパルス

C1 電位

C2 電位

$$
\text { 力 }
$$

発振出力

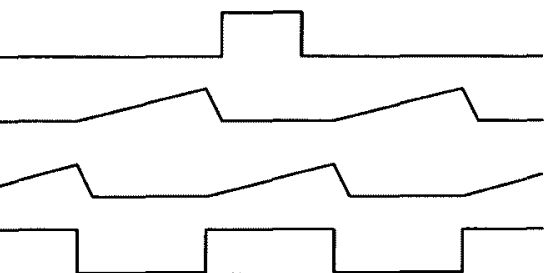

(d)

図 8 図 7 の動作波形

Fig.8. Operating waveforms of Fig. 7
〈4・3〉VCO の面接位相制御によるビット位相同期回路 の特徵 PLLによるビット位相同期回路はPLLループ を経て位相を調整しているのに対し，この回路においては 位相調整は入力信号によって直接行われる。したがって, 同期引き込みが極めて速く，バースト信号にも適用可能で ある。同様に Gated VCOを用いてバースト信号用ビット 位相同期回路を実現した例が報告されている(17)(18)。

反面，PLLのルーブフィルタのように大きな時定数を持 つものが無いため，本質的に長い同符号連続には対応でき ない。同符号連続耐量はVCOの自走発振周波数精度で決 定される。例えば自走発振周波数が入力データ信号速度と $5 \%$ れていると，10 周期後には位相が 180 度ずれてしま う。オンチップ VCO では外部クロックに同期させたリフ アレンス PLL を用いたりして自走発振周波数精度を向上 させることができる。

外付け回路が不要で集積回路化に適している他，回路の 動作速度はデー夕速度と等しく，回路規模も小さい。また 複数チャネルを同一チップに集積した場合でも PLLのよ うな干涉現象による不具合の可能性が低い。

\section{5. 実験結果}

$0.5 \mu \mathrm{mCMOS} フ ゚ ロ セ ス を$ 用いて図 7 に示すVCO の直 接位相制御によるビット位相同期回路を試作した(15)(16)。試 作回路は定格電圧 $3.3 \mathrm{~V}$ で設計し，56ピンプラスチックパ ックージに封止した。ビット位相同期回路部のサイズは $0.5 \mathrm{~mm}^{2}$ である。

試作回路にデータ信号を入力し, VCOの発振波形と再生 データをモタするとともに，データの誤り率を測定した。

図 9 は 440Mbps の連続した擬似ランダムパタン(シーケ ンス長 $2^{23}$.1, 同符号連続最大 23 ビット)を入力した場合の ビット位相同期特性を示している。良好なビット位相同期 が実現しておうり，ビット誤りの発生も見られない。この場 合には同符号連続は最大 23 ビットである。再生クロック のジッタは 70ps rms である。

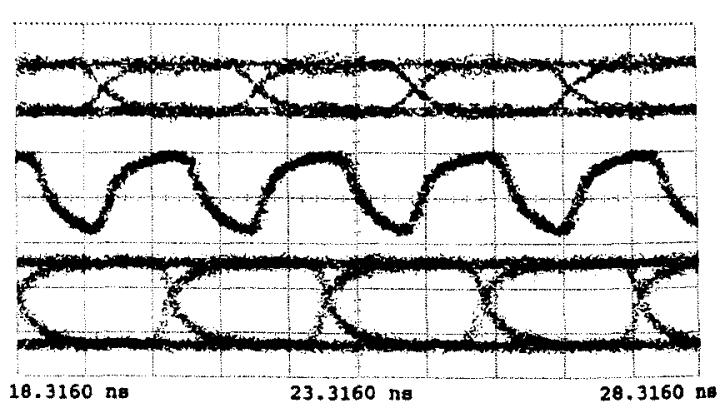

図 9 連続データ信号に対するビット位相同期波形 上段:入カデータ信号 $(440 \mathrm{Mbps}$ 擬似ランダムパタン)

中段:VCO 出力(抽出クロック)

下段:再生データ信号

Fig. 9. Operating waveforms from a random pattern 


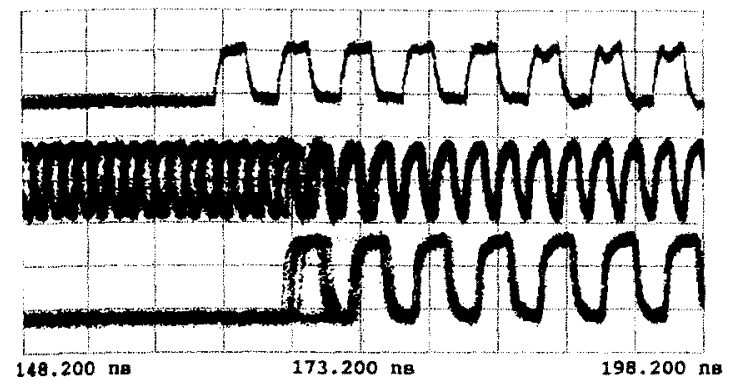

図10バースト信号に対するビット位相同期波形 上段:入カデータ信号

(440Mbps,2000 個の"0"パタンの後の"1010...”バタン) 中段:VCO 出力(抽出クロック)

下段:再生データ信号

Fig. 10. Operating waveforms from a burst data

図 10 は入力パタンに 2000 ビット分の”0"パタンを挿入 することによりバースト信号を模擬した信号を入力した際 のビット同期特性を示す。この場合にも良好にビット位相 同期を実現している。バースト信号の先頭に配置されるプ リアンブルのビット列(“1010...”)の 3 ビット目でビット同 期が実現していることが確認できる。

\section{6. 考察}

ここで提案したビット位相同期回路について，装圈内で 多用するビット位相同期回路として見た場合の 2 章で述 べた各条件の達成状況を評価する。

〈6・1〉入カデータ信号形式に対する適応性図 10 の実験結果にも示されているとおり，位相同期動作は極め て高速でバースト信号などに適用可能である。一方原理的 に同符号連続量が長いデータ信号に対しては不利であり， 図 9 の実験結果では同符号連続長 23 で動作しているが, 集 積回路上の VCOの自走周波数の実用的な精度を $5 \%$ 程度と見 込むと，同符号連続を 5 以下に制限できる $8 \mathrm{~B} 10 \mathrm{~B}$ 符号のよ うな信号形式に適している。信号形式の決定に融通性があ る装置内伝送路には十分適用可能と言える。なお同符号連 続耐量を大きくするためには，VCO の自走周波数の精度を 高くする方策や，図 3 の位相制御トリガパルス生成回路を 工夫する方策などがある(19)。

〈6-2〉 クロック分配経路 ビット位相同期動作自体 には別経路によるクロックの分配は不要である。また送信 側のデータ位相が変動しても追従することができる。

〈6・3〉 入力信号の歪みおよびジッタ特性 入力信号の ジッタには高速に追徉することができる。しかし極端に歪 んだ信号や雑音により誤った位相制御卜リガパルスが生成
されると VCOの発振位相の同期がはずれる可能性がある。 一方図 9 に見られるようにタンク回路を用いた回路に比較 して再生されたクロック出力のジッタは大きいので，デー 夕出力を後段の装置のロ一カルクロックに載せ換えた後好 理を行うことが必要である。いずれにしても装置内での信 号伝送では問題なく使用できる。

〈6・4〉 コスト要因全て集積回路上に構成できるた め，外付け部品や調整は不要である。純ディジタルの回路 に比較すると検查は複雑であるが，通常の周波数シンセサ イザLSI と同程度である。回路規模はVCOのサイズによる が，ディジタル回路を中心に構成されたものに比較して小 さく，加消費電力も小さくできる。電源電圧については ディジタル回路と同様で特に制約はない。これらの特徵は 装置内で多用する場合に有利である。

\section{7. まとめ}

通信装置などに多用されるビット位相同期回路の持つべ き特性と実現方法について考察し, VCOの值接位相同期に よるビット位相同期回路を提案し，武作結果を報告した。 この回路方式は同符号連続耐量は比較的小さいが，回路規 模が小さく，かつ集積回路化に適している。

(平成 8 年 12 月 25 日受付, 平成 9 年 4 月 2 日再受付)

\section{文献}

(1) Takashi Taya, Toshiyuki Tahara, Yoshikatsu Shiraishi : "A Family of Interface LSIs for 155 - 2488 Mbps per Channel Data Transmission within ATM Switch Equipments", IEEE Workshop on VLSI in Communications (Sep. 1993).

(2) Robert Cordell, J. Forney, Charles Dunn, William Garrett : "A 50MHz Phase- and Frequency-Locked Loop", IEEE J. Solid-State Circuits, vol.SC-14, No.6, 1003-1010 (Dec. 1979).

(3) R. Baumert, P. Mets, M. Pedersen, R. Pritchett, J. Young : "A Monolithic $50-200 \mathrm{MHz}$ CMOS Clock Recovery and Retiming Circuit", IEEE Custom Integrated Circuits Conference, 14.5.1 (May 1989).

(4) Robert Cordell : "A 45-Mbit/s CMOS VLSI Digital Phase Aligner", IEEE J. Solid-State Circuits, vol.23, No. 2, 323-328 (Apr. 1988).

(5) 吉田 聡 - 山岡信介・松本修一・横渾幸一・横山友信 太矢隆士：「フレーム同期信号を用いたビット位相同 期回路方式の一検討」，1995 年電子情報通信学会絰合 大会B-593(1995 年 3 月)。

(6) 丹羽一夫：トランジスタ活用ハンドブック，CQ出版， $326(1968$ 年 5 月)。

(7) 吉田 聡・山岡信介・太矢隆士：「装置内高速シリアル 伝送用デー夕再生回路の一検討」，1992 電子情報通信 
学会春季大会 B·798(1992 年 3 月)。

(8) 太矢隆士 - 吉田 聡- 松本修一・横山司昌・吉田良和 : 「VCO の直接位相制御によるクロック再生回路」, 電 気学会電子回路研究会 ECT-94-41(1994 年 10 月)。

(9) 吉田良和・横山司昌・太矢隆士 - 水永 直 : 「 $3.3 \mathrm{~V}$ $800 \mathrm{Mbps}$ シリアル伝送用データ再生回路の検討」, 1995 年電子情報通信学会総合大会 B-954 (1995 年 3 月)。

（10）吉田良和・横山司昌 -太矢隆士 - 吉田 聡 - 龟井孝浩 · 水永 直: 「VCO 直接位相制御方式を用いた $3.3 \mathrm{~V}$ 777.6Mbps デー夕再生回路」, 1996 年電子情報通信 学会ソサイエティ大会 B-905 (1996 年 9 月)。

(11) 太矢隆士・吉田良和・横山司昌：「集積回路 VCO の 高性能化に関する一考察」, 電気学会電子回路研究会 ECT-96-42 (1996 年 6 月)。

(12) 横山司昌 $\cdot$ 太矢隆士 - 吉田 聡・松本修一・水永 直:

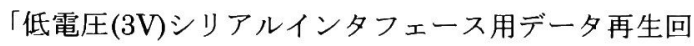
路の一検討」, 1994 電子情報通信学会春季大会 B537 (1994 年 3 月)。

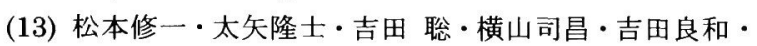
亀井孝浩：「低電圧 $(3 \mathrm{~V})$ シリアルインタフェース用デ 一夕再生回路の試作」, 1994 電子情報通信学会秋季大 会 B-420 (1994 年 9 月)。

(14) 吉田良和 -太矢隆士 - 吉田 聡 - 横山司昌 - 水永 直: 「3.3V 250Mbps バースト信号対応シリアル伝送 LSI」, 1996 年電子情報通信学会総合大会 B-1009 (1996 年 3 月)。

(15) Akira Yoshida, Takashi Taya, Nobusuke Yamaoka, Shuichi Matsumoto, Tomonobu Yokoyama : "A Data Recovery Circuit for Burst Signal Using $440 \mathrm{MHz}$ CMOS Direct Phase Controlled VCO", IEEE Symposium on VLSI Circuit, 11.3 (Jun. 1996).

(16) 太矢隆士・吉田 聡・山岡信介・松本修一：「440Mbps CMOS ビット位相同期回路」, 平 8 電気学会電子・情 報・システム部門大会, A-1-9 (1996 年9月)。

(17) Mihai Banu, Alfred Dunlop : "A 660Mb/s CMOS Clock Recovery Circuit with Instantaneous Locking for NRZ Data and Burst-Mode Transmission", IEEE ISSCC Tech. Dig., 102-103 (Feb. 1993).

(18) Alfred Dunlop, Wilhelm Fischer, Mihai Banu, Thaddeus Gabara : "150/30Mb/s CMOS NonOversampled Clock and Data Recovery Circuits with Instantaneous Locking and Jitter Rejection", IEEE ISSCC Tech. Dig., 44-45 (Feb. 1995).

(19) Nobusuke Yamaoka, Takashi Taya, Akira Yoshida, Masao Kamio and Tomonobu Yokoyama : "A CMOS Data and Clock Recovery Macrocell for BurstMode/Continuous-Mode Transmissions", Proceedings of IEEE 1997 Custom Integrated Circuits Conference, 4.2 (May 1997).
太矢 隆士 (正員) 1960 年 4 月 3 日生まれ。1983年京

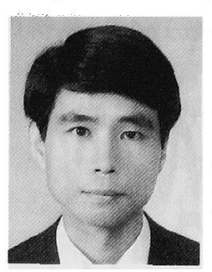
都大学工学部電子工学科卒業。1985 年同 大学大学院工学研究科修士課程修了。同 年沖電気工業(株)入社。B-ISDN 通信装置 ハードウェアおよび LSI の開発に従事。 IEEE，電子情報通信学会会員。

吉田 聡 （非会員）1965 年 1 月 25 日生まれ。1988

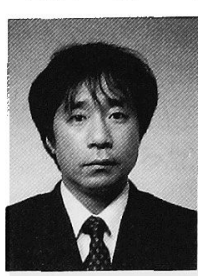

年東京都立大学電気工学科卒業。同年沖電 気工業(株)入社。B-ISDN 通信装置用高速 シリアルインタフェース LSI 設計に従事。 IEEE，電子情報通信学会会員。

山岡 信介（非会員）1966 年 2 月 20 日生まれ。 1989

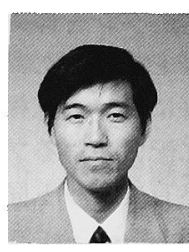
年秋田大学電子工学科卒業。同年沖電気工 業（株）入社。B-ISDN 通信装置ハードウ ェアおよびLSI の開発に従事。IEEE，電 子情報通信学会会員。

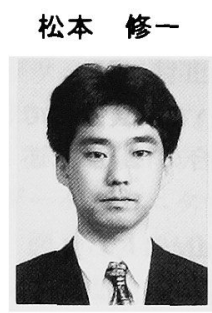

（非会員）1968 年 6 月 25 日生まれ。1991 年帝京技術科学大学 (現帝京平成大学) 情 報工学科卒業。同年沖電気工業（株）入社 ATM 交換機ハードウェアおよびLSI の開 発に従事。電子情報通信学会会員

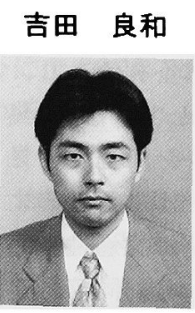

（非会員）1970 年 6 月 6 日生まれ。1993 年同志社大学機械工学科卒業。同年沖電気 工業(株)入社。B-ISDN 通信装置用 LSI $の$ 開発に従事。電子情報通信学会会員。 